\title{
Ultrastructure, morphology and flux of microzoo- plankton faecal pellets in an east Antarctic fjord
}

\author{
Karin L. Beaumont ${ }^{1,2, *}$, Geraldine V. Nash ${ }^{2}$, Andrew T. Davidson ${ }^{2}$ \\ ${ }^{1}$ School of Zoology, University of Tasmania, Hobart, Tasmania, Australia \\ ${ }^{2}$ Australian Antarctic Division, Channel Highway, Kingston, Tasmania, Australia
}

\begin{abstract}
Small copepods and protozoa are major contributors to heterotrophic biomass in Antarctic waters. They produce small $(<300 \mu \mathrm{m})$ faecal pellets, the fates of which are largely unknown. We examined the distribution and abundance of microzooplankton and small faecal pellets in Ellis Fjord, east Antarctica. We determined statistical relationships between the abundance of microzooplankton and pellets, and examined pellet morphology and ultrastructure using light and scanning electron microscopy. Our results indicate species-specific differences in the morphology and fate of pellets produced by small copepods: Oithona similis and harpacticoid pellets were retained in upper waters, while Oncaea curvata and Paralabidocera antarctica pellets sank to depth. Protozoan pellets did not sink to depth irrespective of their source or morphology and despite the fact they can be larger than those produced by small copepods. The majority of microzooplankton pellets, composed of phytoplankton that otherwise may have directly sedimented to depth, was retained in near surface waters and probably recycled and remineralised. Despite producing faecal aggregates, heterotrophic activity of most microzooplankton do not contribute to vertical flux but instead support respiration of matter in upper waters. This may reduce the vertical flux of particulate matter to depth, thereby reducing the capacity of Antarctic waters to act as a carbon sink, with implications for global climate.
\end{abstract}

KEY WORDS: Faecal pellets $\cdot$ Flux $\cdot$ Copepods $\cdot$ Protozoa

\section{INTRODUCTION}

The transfer and vertical flux of photosynthetically fixed carbon in the oceans influences atmosphericocean carbon flux and consequently global climate (Falkowski et al. 1998, Rivkin \& Legendre 2001). Zooplankton play an important role in carbon cycling by packaging planktonic material into faecal pellets that contribute to respiration and nutrient regeneration, or vertical flux (Noji 1991, Banse 1995, Le Fèvre et al. 1998, Wassmann 1998, Turner 2000). However, the contribution by proto- and metazoa to vertical flux, particularly by individual species, is poorly understood. Small copepods have recently been recognised

${ }^{*}$ Present address: Kingston.

Email: karin.beaumont@aad.gov.au as being highly abundant in Antarctic waters, contributing significantly to zooplankton biomass and production (Fransz \& González 1995, Swadling et al. 1997, Metz 1998, Atkinson \& Sinclair 2000). Protozoa are fundamental to the function of the microbial loop, through which most of the carbon flows in marine ecosystems (Fenchel 1988, Froneman \& Perissinotto 1996, Azam 1998). The production of pellets by small copepods has been recognised for some time and these pellets are reportedly respired in near-surface waters (Smetacek 1980, Wassmann et al. 1994, Bathmann 1996, González et al. 2000). In contrast, the production and flux of protozoan pellets have only recently been considered despite the fact that they can be of equivalent size to those produced by small copepods (Buck \& Newton 1995, Gowing et al. 2001).

To better understand the regulation of pellet flux it is necessary to determine the ecology and tropho- 
dynamics of key species (Verity \& Smetacek 1996, Wassmann 1998, MZC2 2001). Studies investigating vertical flux using sediment traps have seldom simultaneously determined the plankton in the overlying water column. This has led to classification of faecal pellets being ill defined and their origins being largely unknown or presumed.

Marine environments that have low species richness, such as Ellis Fjord, provide the opportunity to investigate fine-scale interactions and the role of key species in vertical flux (Trull et al. 2001). In this study, we investigate the distribution, abundance and linkage between microzooplankton and small pellets, from Ellis Fjord, east Antarctica. We examine the morphology and ultrastructure of faecal pellets using light and scanning electron microscopy, and consider the extent to which species-specific trophodynamics and pellet ultrastructure affect the contribution by microzooplankton to vertical flux.

\section{METHODS}

Study site and field sampling. This study was conducted in an east Antarctic fjord, Ellis Fjord $\left(68.5^{\circ} \mathrm{S}\right.$, $78.0^{\circ} \mathrm{E}$ ) in the Vestfold Hills. The fjord is approximately $10 \mathrm{~km}$ long and $1 \mathrm{~km}$ wide, and contains 5 major basins. Our sampling site was located in Middle Basin, which has a maximum depth of approximately $80 \mathrm{~m}$. The majority of the fjord has remained icecovered since 1991 (McMinn 1994, Gibson 1999). While the fjord was ice-covered during this study (December 1997 to March 1998), we observed substantial surface and under-ice melt. Detailed descriptions of the physico-chemical characteristics of the fjord are provided by Gibson $(1998,1999)$. The seasonal succession of the plankton community at the study site forms a separate study (Beaumont et al. unpubl.).

Holes were drilled in the sea-ice using a $20 \mathrm{~cm}$ auger attached to a Jiffy drill. A $100 \mu \mathrm{m}$ mesh umbrella net with a mouth of $28 \times 28 \mathrm{~cm}$ (Kirkwood \& Burton 1987) was deployed to sample the zooplankton community. Net hauls were taken from 5, 10, 20 and $40 \mathrm{~m}$ to surface at each of 3 holes in the ice, thereby providing 3 independent replicate hauls for each depth. The samples were preserved in Steedman's solution containing $5 \%$ buffered formalin, $4.5 \%$ propylene glycol, and $0.5 \%$ propylene phenoxytol (Steedman 1976).

A 21 Kemmerer bottle was used to obtain water samples at approximately weekly intervals to examine the protistan community in the water column. Three replicate samples were taken at 5, 10, 20 and $40 \mathrm{~m}$. The sample was transferred to a 21 polycarbonate jar, placed in a dark, insulated container, and transported to the laboratory.
Sediment traps were deployed through $20 \mathrm{~cm}$ diameter holes drilled through the ice cover of the fjord. The traps consisted of a cylindrical section (internal diameter $65 \mathrm{~mm}, 6: 1$ aspect ratio) connected to a funnel that tapered into a cylindrical collector tube after Bloesch \& Burns (1980) and Rosa et al. (1994). The traps were filled with $0.2 \mu \mathrm{m}$ filtered seawater to which $50 \mathrm{~g} \mathrm{l}^{-1}$ sodium chloride and $6.5 \times 10^{-4} \mathrm{~g} \mathrm{l}^{-1}$ mercuric chloride had been added to minimise loss of material during retrieval and in situ bacterial production (Knauer et al. 1984, Lee et al. 1992). Three replicate traps were suspended at depths of 5,10,20 and $40 \mathrm{~m}$ in the water column and samples were obtained weekly. For further details regarding the field-sampling regime, see Beaumont et al. (2001). The fixed samples, containing faecal pellets, were analysed in the laboratory upon return to Australia.

We attempted to measure current speeds at the study site using flowmeters, but problems with ice conditions (clogging of the meter) and the stability of the vane rendered the data unreliable. High flow rates have been recorded through the narrow seaward entrance to the fjord where the ice often melts completely during summer leaving this entrance exposed to wind-induced turbulence (Kirkwood 1993). However, the flow rate at the landward entrance is low and the ice rarely melts completely. Our study site was located towards the landward end of the fjord and remained ice-covered throughout summer, so turbulence was likely to be low during this study.

Laboratory methods. Net haul samples were examined using a dissecting microscope. The dominant metazoa were identified and counted. Metazoan abundance was calculated using the mouth area of the net and the vertical distance towed, assuming $100 \%$ filtration efficiency. The mean and SE of the 3 replicate samples were determined. However, where samples were lost and there were less than 3 replicate samples, no SE were calculated. The mean abundances were then subtracted from consecutive depths to determine abundance at the following depth intervals: $0-5,5-10$, 10-20, and 20-40 m.

Each 2 l water sample was mixed, and a $500 \mathrm{ml}$ aliquot from each replicate Kemmerer bottle sample was decanted into a measuring cylinder and fixed with acid Lugol's iodine. Samples were left for approximately $24 \mathrm{~h}$ and then the supernatant was removed by aspiration. The remaining sample (approximately $50 \mathrm{ml}$ ) was transferred to a glass, screw-lidded container and refrigerated at 0 to $4^{\circ} \mathrm{C}$ prior to microscopic analysis.

Protozoa were settled in Utermöhl sedimenting chambers, identified and counted using an inverted microscope. Only samples taken during January and February were analysed, as chlorophyll a (chl a) con- 
centration in the water column indicated peak biomass during these months (Beaumont unpubl.). Two independent replicate samples were analysed for each sampling date. Fifteen replicate fields (or portions thereof) were counted per sample and the mean and SE calculated. Dinoflagellates were grouped as autotrophic or heterotrophic by the presence of chlorophyll under transmitted light, starch storage products, and the trophic status according to Tomas (1996). Mixotrophic species were included as protozoa.

Sediment trap samples were left to settle as above and examined using an inverted microscope to identify and enumerate faecal pellets. Faecal pellets were classified into 4 categories based on pellet descriptions from the literature: cylindrical, oval, pellets with intact frustules, and minipellets (Urrere \& Knauer 1981, Gowing \& Silver 1985, González 1992a,b, González et al. 1994a, Buck \& Newton 1995). Subsamples were taken and pellet concentration determined for each replicate, and the grand mean count was calculated. The maximum and minimum values for the 2 replicate samples were used to indicate the variance between traps.

Statistical analyses. Plankton were progressively integrated throughout the overlying water column to corresponding trap depths for the entire summer season. The data were transformed using the log $(x+1)$ transformation to account for heterogeneity and to normalise the distributions in the data. Linear regressions were performed between the integrated abundance of plankton $\left(\mathrm{m}^{-2}\right)$ in the overlying water column and the flux of faecal pellets $\left(\mathrm{m}^{-2} \mathrm{~d}^{-1}\right)$ to traps at each depth (i.e. the faecal pellet abundance at $40 \mathrm{~m}$ was regressed against the plankton abundance from 20-40, 10-40, $5-40$ and $0-40 \mathrm{~m})$. The correlation coefficient was used to determine the statistical significance of these relationships.

Microscopy. To obtain a representative cross-section of pellet types throughout the season, weekly samples were pooled for the examination of pellet morphology and ultrastructure.

Whole faecal pellets: Faecal pellets were isolated by micro-pipette and transferred to a droplet of $0.2 \mu \mathrm{m}$ filtered seawater. The water containing the pellet was mixed and the isolation repeated until the pellet was free from extraneous organic matter. Faecal pellets were then separated according to their morphology, and photographed under natural light at $400 \times$ magnification using a Leitz Fluovert inverted microscope.

Various methods were used to minimise disruption of the faecal pellets during preparation for scanning electron microscopy (SEM). Oval and minipellets were pipetted onto $25 \mathrm{~mm}$ diameter Nuclepore filters (5.0 $\mu \mathrm{m}$ pore size) and blotted to remove excess water. A subsample of an entire trap sample that contained faecal pellets and other matter was also pipetted directly onto a Nuclepore filter to examine the complete array of pellets in the trap. Pellets containing whole diatom frustules, were pipetted onto glass microscope slides that had been coated with polylysine (Marchant \& Thomas 1983). Cylindrical pellets were pipetted into a Nuclepore filter 'basket' that consisted of 2 layers of filter paper wedged between magnet rings. The filters and slides with attached samples were placed in petri dishes, gently washed with $10 \%$ ethanol to remove traces of mercuric chloride, and fixed with osmium tetroxide vapour. They were then dehydrated through a graded ethanol series followed by a concentrated solution of hexamethyl disilizane, and dried in a fume hood. The samples were subsequently mounted on carbon tabs with silver paint, and then on stubs, sputter coated with gold, and examined by SEM.

Faecal pellet contents: Faecal pellets had been preserved in mercuric chloride that reportedly inhibits bacterial ectoenzyme activity in seawater (Christian \& Karl 1995). However, the extent to which mercuric chloride penetrates the faecal pellet is unknown. Pellets with membranes that masked the pellet contents were rinsed and pipetted into $0.2 \mu \mathrm{m}$ filtered seawater and placed in an oven at $20^{\circ} \mathrm{C}$ for $24 \mathrm{~h}$ to allow for potential microbial stripping of the membrane (Turner 1984). In the event that microbial stripping did not occur, we concurrently adapted a method used to clean diatom frustules and placed pellets in 50\% hydrogen peroxide for 2 to $3 \mathrm{~d}$ (Battarbee 1986). All pellets were subsequently pipetted onto Nuclepore filters and prepared for SEM (see above).

\section{RESULTS}

\section{Plankton}

This study examined the distribution and abundance of micro-pellets and their relationship with the dominant plankton in the water column. Several copepod species (Ctenocalanus citer Heron \& Bownman, Drepanopus bispinosis Bayly, Stephos longipes Giesbrecht and Paraeuchaeta antarctica Giesbrecht), a larvacean, and echinoid larvae were not included in our analyses due to their low or brief periods of abundance. In addition, pellets typical of the large, common, Antarctic copepod Calanoides acutus Giesbrecht were not observed; the morphology of pellets produced by ctenophores is unknown (Reeve \& Walter 1978), and pellets produced by heterotrophic nanoflagellates are reportedly too small (approximately $1 \mu \mathrm{m}$ ) to be detected by the methods used in this study (Elbrachter 1991). Therefore, these plankton taxa are not considered any further. 
Small copepods were abundant throughout this study, especially in the upper $20 \mathrm{~m}$ of the water column, and showed extremely high spatial variability (SE from 1 to $100 \%$ of the mean) (Table 1). Oncaea curvata was the dominant copepod (Fig. 1a, Table 1). This species in-

Table 1. Mean abundance of copepods (ind. $\mathrm{m}^{-2}$, mean $\pm \mathrm{SE}$ ) at depth intervals from surface to $40 \mathrm{~m} .{ }^{*}<3$ replicate samples where no SE was calculated

\begin{tabular}{|c|c|c|c|c|}
\hline Date $^{a}$ & $0-5 \mathrm{~m}$ & $0-10 \mathrm{~m}$ & $0-20 \mathrm{~m}$ & $0-40 \mathrm{~m}$ \\
\hline \multicolumn{5}{|c|}{ Oncaea curvata } \\
\hline $16 / 12 / 97$ & $0^{*}$ & $94 \pm 32$ & $232 \pm 91$ & $325^{*}$ \\
\hline $23 / 12 / 97$ & $281 \pm 141$ & $957 \pm 145$ & $1257 \pm 52$ & $1790 \pm 26$ \\
\hline $28 / 12 / 97$ & $212 \pm 153$ & $991 \pm 283$ & $2934 \pm 1046$ & $3900 \pm 1314$ \\
\hline 4/1/98 & $434 \pm 124$ & $1967 \pm 275$ & $4344 \pm 887$ & $4443 \pm 1386$ \\
\hline $11 / 1 / 98$ & $592 \pm 217$ & $1208 \pm 401$ & $4739 \pm 690$ & $4566 \pm 1750$ \\
\hline $18 / 1 / 98$ & $128 \pm 32$ & $735 \pm 223$ & $2505 \pm 226$ & $3826 \pm 408$ \\
\hline 25/1/98 & $10 \pm 10$ & $108 \pm 51$ & $789 \pm 256$ & $2199 \pm 403$ \\
\hline $1 / 2 / 98$ & $64 \pm 10$ & $74 \pm 31$ & $680 \pm 157$ & $1425 \pm 43$ \\
\hline 8/2/98 & $79 \pm 20$ & $44 \pm 9$ & $1045 \pm 156$ & $1637 \pm 590$ \\
\hline $18 / 2 / 98$ & $79 \pm 18$ & $49 \pm 13$ & $104 \pm 39$ & $1755 \pm 271$ \\
\hline $4 / 3 / 98$ & $59-$ & $35 \pm 5$ & $192 \pm 31$ & $986 \pm 124$ \\
\hline \multicolumn{5}{|c|}{ Paralabidocera antarctica } \\
\hline $16 / 12 / 97$ & $22^{*}$ & $15 \pm 9$ & $0-$ & $0^{*}$ \\
\hline 23/12/97 & $79 \pm 30$ & $84 \pm 18$ & $5 \pm 5$ & $20 \pm 5$ \\
\hline $28 / 12 / 97$ & $30 \pm 30$ & $35 \pm 18$ & $20 \pm 13$ & $20 \pm 10$ \\
\hline $4 / 1 / 98$ & $69 \pm 30$ & $64 \pm 18$ & $69 \pm 25$ & $64 \pm 36$ \\
\hline $11 / 1 / 98$ & $5 \pm 5$ & $25 \pm 5$ & $54 \pm 18$ & $20 \pm 13$ \\
\hline 18/1/98 & $30 \pm 15$ & $84 \pm 13$ & $182 \pm 21$ & $138 \pm 13$ \\
\hline $25 / 1 / 98$ & $15 \pm 9$ & $15 \pm 15$ & $30 \pm 23$ & $99 \pm 30$ \\
\hline $1 / 2 / 98$ & $30 \pm 15$ & $44 \pm 30$ & $84 \pm 35$ & $99 \pm 44$ \\
\hline $8 / 2 / 98$ & $0-$ & $0-$ & $54 \pm 30$ & $84 \pm 10$ \\
\hline $18 / 2 / 98$ & $5 \pm 5$ & $5 \pm 5$ & $5 \pm 5$ & $10 \pm 5$ \\
\hline $4 / 3 / 98$ & $0 \quad-$ & $0-$ & $0-$ & $0 \quad-$ \\
\hline \multicolumn{5}{|c|}{ Oithona similis } \\
\hline $16 / 12 / 97$ & $0^{*}$ & $0-$ & $10 \pm 10$ & $15^{*}$ \\
\hline 23/12/97 & $25 \pm 10$ & $5 \pm 5$ & $10 \pm 10$ & $35 \pm 18$ \\
\hline 28/12/97 & $5 \pm 5$ & $5 \pm 5$ & $10 \pm 5$ & $35 \pm 18$ \\
\hline 4/1/98 & $5 \pm 5$ & $15 \pm 9$ & $20 \pm 13$ & $59 \pm 17$ \\
\hline $11 / 1 / 98$ & $25 \pm 5$ & $35 \pm 18$ & $123 \pm 75$ & $123 \pm 101$ \\
\hline $18 / 1 / 98$ & $49 \pm 35$ & $69 \pm 10$ & $108 \pm 32$ & $104 \pm 15$ \\
\hline $25 / 1 / 98$ & $20 \pm 5$ & $44 \pm 15$ & $49 \pm 26$ & $49 \pm 20$ \\
\hline $1 / 2 / 98$ & $64 \pm 13$ & $74 \pm 48$ & $242 \pm 25$ & $217 \pm 39$ \\
\hline 8/2/98 & $35 \pm 5$ & $39 \pm 13$ & $222 \pm 112$ & $237 \pm 87$ \\
\hline $18 / 2 / 98$ & $20 \pm 13$ & $49 \pm 42$ & $104 \pm 17$ & $25 \pm 25$ \\
\hline $4 / 3 / 98$ & $0 \quad-$ & $64 \pm 13$ & $148 \pm 30$ & $375 \pm 49$ \\
\hline \multicolumn{5}{|c|}{ Harpacticoids } \\
\hline $16 / 12 / 97$ & $0^{*}$ & $0-$ & $0 \quad-$ & $0^{*}$ \\
\hline $23 / 12 / 97$ & $0-$ & $0-$ & $0-$ & $0-$ \\
\hline $28 / 12 / 97$ & $\begin{array}{ll}0 & -\end{array}$ & $0 \quad-$ & $0-$ & 0 \\
\hline 4/1/98 & $15-$ & $10 \pm 10$ & $0-$ & 0 \\
\hline $11 / 1 / 98$ & $0 \quad-$ & $0 \quad-$ & $5 \pm 5$ & $0 \quad-$ \\
\hline 18/1/98 & $64 \pm 10$ & $25 \pm 10$ & $84 \pm 40$ & $39 \pm 13$ \\
\hline $25 / 1 / 98$ & $25 \pm 10$ & $44 \pm 15$ & $20 \pm 10$ & $10 \pm 10$ \\
\hline $1 / 2 / 98$ & $0 \quad-$ & $30 \pm 9$ & $15-$ & $5 \pm 5$ \\
\hline 8/2/98 & $0-$ & $5 \pm 5$ & $20 \pm 10$ & $0-$ \\
\hline $18 / 2 / 98$ & $0-$ & $0-$ & $0 \quad-$ & 0 \\
\hline $4 / 3 / 98$ & $0-$ & 0 & 0 & 0 \\
\hline
\end{tabular}

creased in abundance during December to peak in January, but declined in February and March (Fig. 1a). Paralabidocera antarctica, Oithona similis and harpacticoid copepods were in much lower abundance than $O$. curvata (averaging $<30 \mathrm{~m}^{-3}$ ) (Fig. 1a,b). P. antarctica was present throughout December and January, but declined in February and was absent in March. In contrast, O. similis peaked during February and early March while harpacticoids exhibited a brief peak in mid January (Fig. 1b).

Heterotrophic dinoflagellates (HDIN) were in low concentration throughout January, but increased to a peak concentration of $6.33 \pm 0.66 \times 10^{7} \mathrm{~m}^{-3}$ at $\leq 5 \mathrm{~m}$ in early February (Fig 1c). HDIN concentration was similarly high between 5 and $10 \mathrm{~m}$ at this time, while the concentration at $\geq 20 \mathrm{~m}$ depth increased later in the month. Mixotrophic Ceratium spp. dominated the HDIN taxa, however Gyrodinium spp., and Katodinium spp. contributed to the HDIN concentration during late summer. Amphidinium spp. and Protoperidinium spp. were also present in low concentrations but reached maximum concentrations on 18 February of $8.92 \pm$ $1.35 \times 10^{6} \mathrm{~m}^{-3}$ between 10 and $20 \mathrm{~m}$, and $4.54 \pm 3.63 \times 10^{6} \mathrm{~m}^{-3}$ between 20 and $40 \mathrm{~m}$ respectively. Gymnodinium spp. were also abundant, but it is likely that most of the species we observed were autotrophic as the cells contained chloroplasts. Therefore, the abundance of this taxon was not included in the total HDIN abundance.

Ciliates comprised Strombidium spp., oligotrich genera, and tintinnids. The concentration of ciliates was much lower than that of HDIN but showed a similar temporal pattern of abundance. Ciliate concentration was low throughout January but increased in the upper $10 \mathrm{~m}$ in midFebruary, with the peak concentration of of $3.96 \pm 0.38 \times 10^{7} \mathrm{~m}^{-3}$ at $\leq 5 \mathrm{~m}$ (Fig. 1c) However, in contrast to that of HDIN, ciliate concentration at depths $\geq 20 \mathrm{~m}$ remained low throughout the season. Overall, the concentration of both HDIN and ciliates was highly variable (Fig. 1c).

\section{Faecal pellets}

Cylindrical pellets were most abundant from December to January, with a peak 

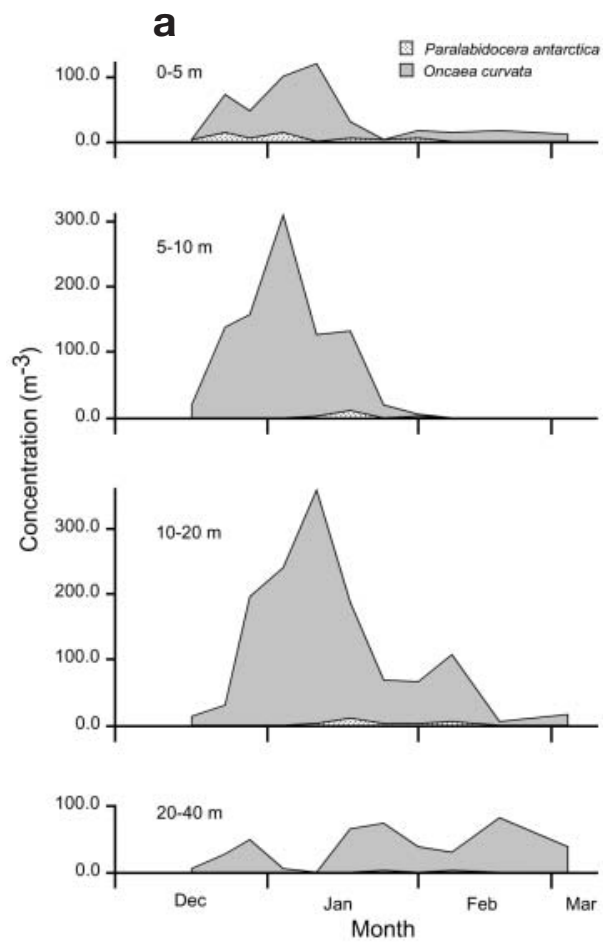
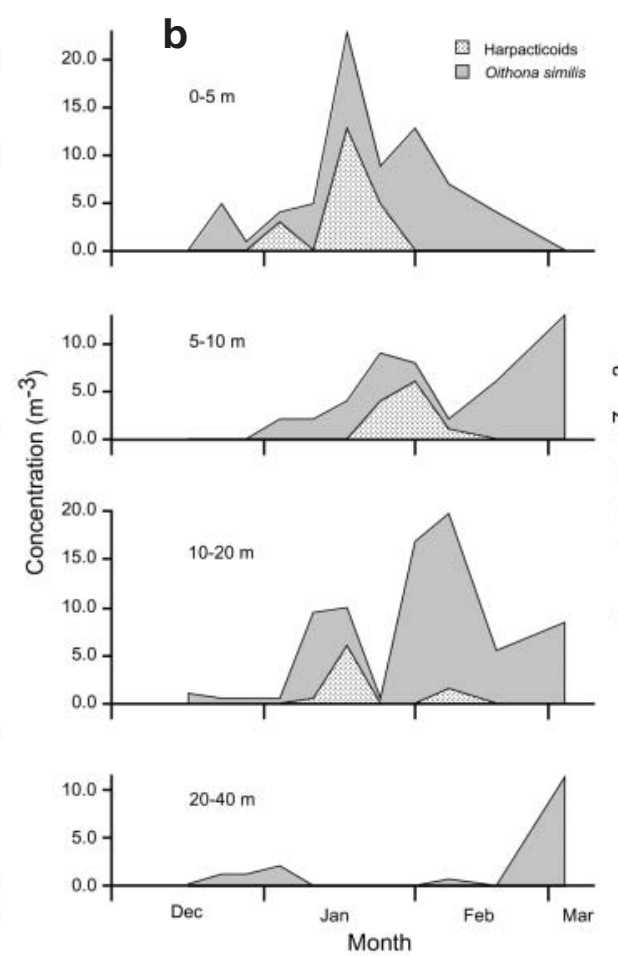
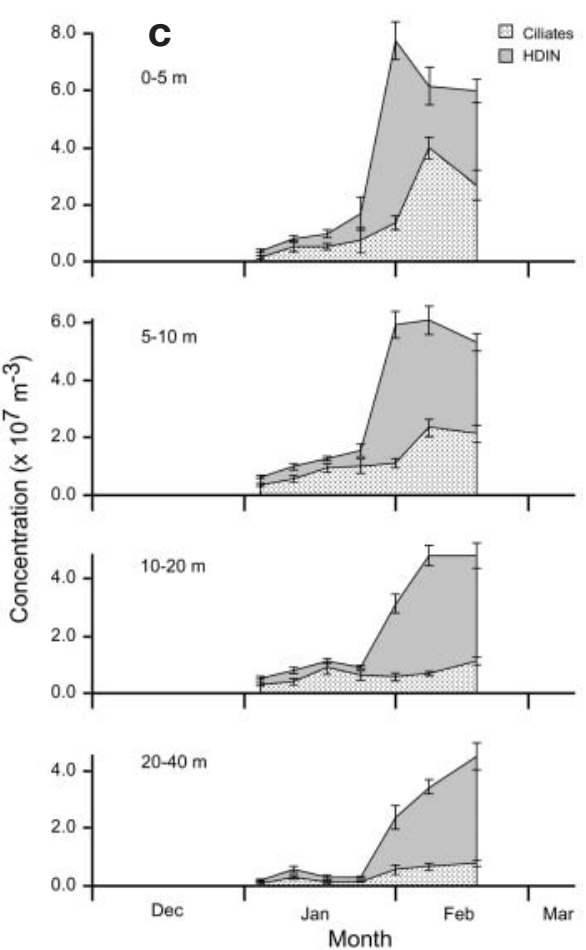

Fig. 1. Abundance of (a) Oncaea curvata and Paralabidocera antarctica, (b) Oithona similis and harpacticoids, and (c) heterotrophic dinoflagellates (HDIN) and ciliates (error bars represent \pm 1 SE) in the water column

flux of $1.20 \pm 0.70 \times 10^{4}$ pellets $\mathrm{m}^{-2} \mathrm{~d}^{-1}$ observed at $40 \mathrm{~m}$, but generally declined during February and March (Fig. 2a). Oval pellets dominated total pellet flux with a sedimentation peak of $5.24 \pm 1.54 \times 10^{5}$ pellets $\mathrm{m}^{-2} \mathrm{~d}^{-1}$ recorded at $5 \mathrm{~m}$ in late January. Sedimentation of these pellets persisted until late February in the upper $10 \mathrm{~m}$ of the water column. The flux of oval pellets to $\geq 20 \mathrm{~m}$ in the water column was low throughout this study.

Pellets containing only intact frustules sedimented throughout most of the season, predominantly in the upper water column, reaching $1.27 \pm 0.89 \times 10^{5}$ pellets

Table 2. Significant correlations (all positive) between plankton species and pellet types

\begin{tabular}{|c|c|c|c|c|c|c|}
\hline Organism & Pellet type & $\begin{array}{l}\text { Water column } \\
\text { above trap depth }\end{array}$ & $\begin{array}{l}\text { Trap } \\
\text { depth }\end{array}$ & $\mathrm{r}$ & $\mathrm{n}$ & Probability \\
\hline \multirow[t]{2}{*}{ Oithona similis } & Cylindrical & $0-5$ & 5 & 0.656 & 11 & $0.02<\mathrm{p}<0.05$ \\
\hline & Minipellets & $10-20$ & 20 & 0.622 & 11 & $0.02<\mathrm{p}<0.05$ \\
\hline Harpacticoids & Minipellets & $5-40$ & 40 & 0.641 & 11 & $0.02<\mathrm{p}<0.05$ \\
\hline \multirow[t]{5}{*}{ HDIN } & Minipellets & $0-10$ & 10 & 0.754 & 7 & $0.02<\mathrm{p}<0.05$ \\
\hline & Minipellets & $5-10$ & 10 & 0.798 & 7 & $0.02<\mathrm{p}<0.05$ \\
\hline & Minipellets & $0-20$ & 20 & 0.920 & 7 & $0.002<\mathrm{p}<0.005$ \\
\hline & Minipellets & $5-20$ & 20 & 0.913 & 7 & $0.002<\mathrm{p}<0.005$ \\
\hline & Minipellets & $10-20$ & 20 & 0.890 & 7 & $0.02<\mathrm{p}<0.05$ \\
\hline \multirow[t]{2}{*}{ Ciliates } & Minipellets & $0-10$ & 10 & 0.876 & 7 & $0.005<\mathrm{p}<0.01$ \\
\hline & Minipellets & $5-10$ & 10 & 0.827 & 7 & $0.02<\mathrm{p}<0.05$ \\
\hline
\end{tabular}

$\mathrm{m}^{-2} \mathrm{~d}^{-1}$ at $10 \mathrm{~m}$ in mid-January and $1.15 \pm 0.72 \times 10^{5}$ pellets $\mathrm{m}^{-2} \mathrm{~d}^{-1}$ in early February. In contrast, minipellets showed only a brief period of sedimentation in the water column in mid February (Fig. 2b). In general, the flux of minipellets to $\leq 20 \mathrm{~m}$ was low and highest flux was observed at $40 \mathrm{~m}\left(2.92 \pm 0.53 \times 10^{5}\right.$ pellets $\left.\mathrm{m}^{-2} \mathrm{~d}^{-1}\right)$.

\section{Plankton and faecal pellet correlations}

While most plankton taxa did not correlate with the abundance of pellets in traps, significant correlations were observed between microzooplankton taxa and pellet types (Table 2).

The abundance of Oncaea curvata and Paralabidocera antarctica from early to mid summer (December to January) coincided with the flux of cylindrical faecal pellets in the water column. In particular, the occurrence of pellets at $40 \mathrm{~m}$ resembled the abundance of these species of plankton between 10 and $20 \mathrm{~m}$ (Figs. 1a \& 2a). No significant correlations were observed between the abundance of these species and that of 

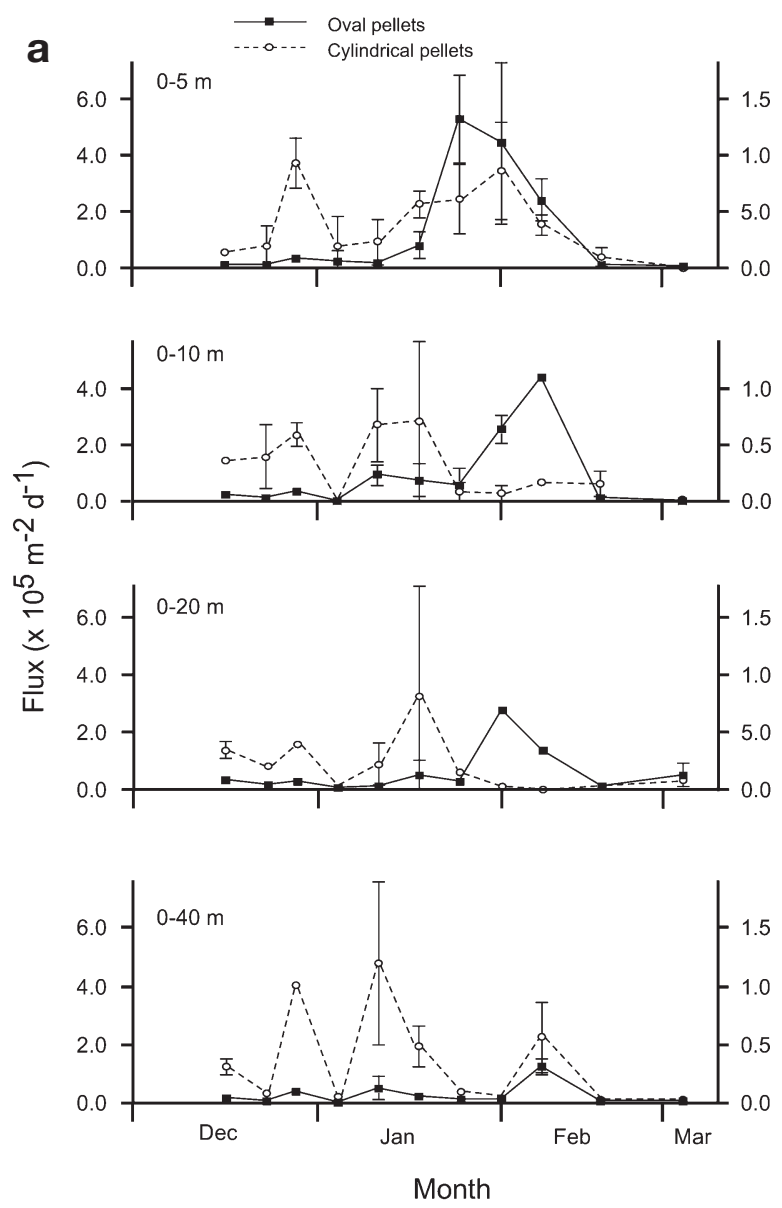

cylindrical pellets. However, the abundance of $P$. antarctica between 5 and $10 \mathrm{~m}$ and the flux of cylindrical pellets to $10 \mathrm{~m}$ showed a relationship that approached significance $(0.05<\mathrm{p}<0.10)$.

The abundance of Oithona similis and harpacticoids in late January and February coincided with the flux of oval pellets in the water column (Figs. 1b \& 2a), and near-significant correlations were observed between the two $(0.05<\mathrm{p}<0.10)$. Oithona similis and harpacticoids at $\geq 20 \mathrm{~m}$ significantly correlated with the flux of minipellets to 20 and $40 \mathrm{~m}$ respectively (Table 2), and the abundance of $O$. similis in the upper $5 \mathrm{~m}$ showed a near-significant correlation with the flux of minipellets to $5 \mathrm{~m}(0.05<\mathrm{p}<0.10)$. Furthermore, the abundance of $O$. similis showed a consistent, but not significant, negative relationship $(-0.989<$ slope $<-0.831)$ with the abundance of cylindrical pellets at depth intervals throughout the water column (data not shown), except at $\leq 5 \mathrm{~m}$ where we observed a significant positive correlation between $O$. similis and cylindrical pellets.

Heterotrophic dinoflagellates were most abundant from mid to late summer, and pellets with intact frustules were abundant in traps throughout the season (Figs. 1c \& 2b). While both the concentration of organ-
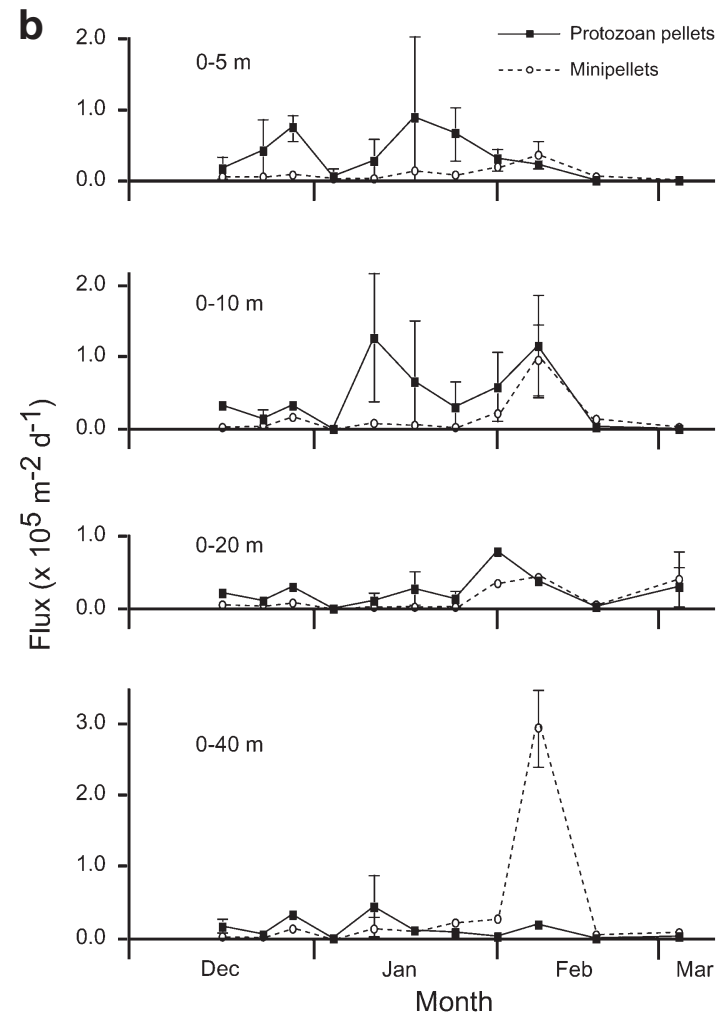

Fig. 2. Flux of (a) oval $\left(\times 10^{5} \mathrm{~m}^{-2} \mathrm{~d}^{-1}\right)$ and cylindrical pellets $\left(\times 10^{4} \mathrm{~m}^{-2} \mathrm{~d}^{-1}\right)$, and (b) pellets with intact frustules (protozoan) pellets and minipellets to 5, 10, 20 and $40 \mathrm{~m}$ depth. Error bars represent minimum and maximum values of the 2 replicate samples

isms and the flux of pellets were greatest in the upper $10 \mathrm{~m}$ of the water column, they were not significantly correlated $(p>0.2)$. In contrast, the concentration of HDIN at depth intervals $\leq 20 \mathrm{~m}$ significantly correlated with the flux of minipellets to traps at 10 and $20 \mathrm{~m}$ depths.

The abundance of ciliates in the upper $10 \mathrm{~m}$ of the water column in mid February coincided with an abundance of minipellets, and a significant correlation was observed between the two at $\leq 10 \mathrm{~m}$.

\section{Faecal pellet morphology and ultrastructure}

Nine different faecal pellet types were discriminated on the basis of their morphology and ultrastructure (Table 3).

\section{Cylindrical pellets}

Cylindrical pellets largely contained diatom fragments with no interstitial connective material, but some whole frustules of Thalassiosira sp., Nitzschia 
Table 3. Types, sizes, contents and probable origin of faecal pellets in sediment traps throughout the upper $40 \mathrm{~m}$ of the water column during summer in Ellis Fjord. Where pellet sizes were consistent the dimensions were averaged. Pellets varying greatly in size are presented as ranges. $\varnothing$ : diameter, MB: membrane bound, DF: fragmented diatom frustules, WD: whole diatom frustules, + or - CM: with or without interstitial connective material

\begin{tabular}{|c|c|c|c|}
\hline Pellet type & $\begin{array}{l}\text { Average or range } \\
\text { in size }(\mu \mathrm{m})\end{array}$ & Contents & Probable origin \\
\hline Cylindrical & $250 \times 73$ & $\mathrm{MB}, \mathrm{DF},-\mathrm{CM}$ & O. curvata and $P$. antarctica \\
\hline Oval & $80 \times 60$ to $190 \times 155$ & $\mathrm{MB}, \mathrm{WD}$ and $\mathrm{DF}$, cysts, $+\mathrm{CM}$ & O. similis and harpacticoids \\
\hline \multicolumn{4}{|l|}{ Intact frustules } \\
\hline Oval & $150 \times 110$ & $\mathrm{MB}, \mathrm{WD}$ of single or multi-species $-\mathrm{CM}$ & Athecate dinoflagellates \\
\hline Irregular & $130 \times 120$ & $\mathrm{MB}, \mathrm{WD}$ of single species, $-\mathrm{CM}$ & Phagotrophic dinoflagellates \\
\hline Round & $150-250 \varnothing$ & $\mathrm{MB}, \mathrm{WD}$ of single species, $-\mathrm{CM}$ & Pallium-feeding dinoflagellates \\
\hline \multicolumn{4}{|l|}{ Minipellets } \\
\hline Oval & $25 \times 18$ to $60 \times 35$ & $\pm \mathrm{MB}, \mathrm{DF}<10 \mu \mathrm{m}$, detritus and crushed material & Dinoflagellates and ciliates \\
\hline Spherical & $60-80 \varnothing$ & MB, DF, WD $>20 \mu \mathrm{m}$ & Copepod nauplii \\
\hline Semi-transparent & $30 \varnothing$ & $\mathrm{MB}, \mathrm{WD}$ & Dinoflagellates \\
\hline False & $50 \varnothing$ & Partially MB, DF & By-product of coprophagy \\
\hline
\end{tabular}

stellata (Mang.) and Nitzschia prolongatoides (Hasle) were observed (Table 3, Fig. 3a-c). We also occasionally observed microbial degradation of the bounding membrane surrounding these pellets (Fig. 3d). Cylindrical pellets were poorly retained on standard Nuclepore filters and polylysine coated microscope slides, and had to be contained in a filter 'basket' during preparation for SEM.

\section{Oval pellets}

Oval faecal pellets were densely packed, membrane bound and varied considerably in size (Table 3, Fig. 3e,f). These pellets largely contained fragmented frustules of Fragillariopsis curta (Van Heurek) Hustedt and Fragillariopsis cylindrus (Grunow) Krieger (Fig. 3g). However, oval pellets also contained filamentous threads and organic matter in the interstitial spaces between frustules (Fig. 3g), and occasional whole diatom frustules, dinoflagellate cysts, and chryosphyte statocysts. Whole frustules were also observed adhered to the outer surface of the pellet (Fig. 3h). The pellets were resilient during handling and preparation in the laboratory, and the membrane remained largely intact after microbial stripping.

\section{Faecal pellets with intact frustules}

Three types of membrane-bound faecal pellets containing intact, empty frustules were evident by light microscopy (LM) (Table 3, Fig. 4a-e). Oval pellets contained either 1 species of diatom (often chain-forming) (Fig. $4 \mathrm{a}, \mathrm{b}$ ), or a variety of intact pennate and centric diatom frustules (Fig. 4c). Irregular and round pellets contained frustules of a single pennate diatom species (Table 3, Fig. 4d,e). All pellets appeared semi-transparent when viewed by LM and some details of the frustules within the pellets were evident through the bounding membrane. In addition, the membrane frequently ruptured during handling and the integrity of the pellet contents was not retained (Fig. 4f).

\section{Minipellets}

Four types of minipellets were evident. It was not possible to determine whether interstitial connective material was present in minipellets. Oval and spherical minipellets appeared consolidated: pellets were opaque under LM and their contents were densely packed. Oval minipellets were observed both with and without a bounding membrane and contained detritus, crushed material and fragments of small ( $<10 \mu \mathrm{m}$ long) diatoms (Table 3, Fig. 5a,b). Spherical minipellets were membrane-bound and contained diatom fragments and whole frustules $>20 \mu \mathrm{m}$ (Table 3, Fig. 5c). Semi-transparent minipellets, discriminated using LM, were small, oval to irregular in shape, membrane-bound, and contained intact pennate diatom frustules (Table 3, Fig. 5d). These pellets were not as common as consolidated minipellets under LM (Fig. 5e). Observation of a complete trap sample by SEM also showed minipellets that were partially membrane-bound (Table 3, Fig. 5f) and resembled the end of a cylindrical pellet (see Fig. 3d).

\section{DISCUSSION}

Microcopepods and protozoa are major contributors to heterotrophic biomass in the oceans (Lessard 1991, 

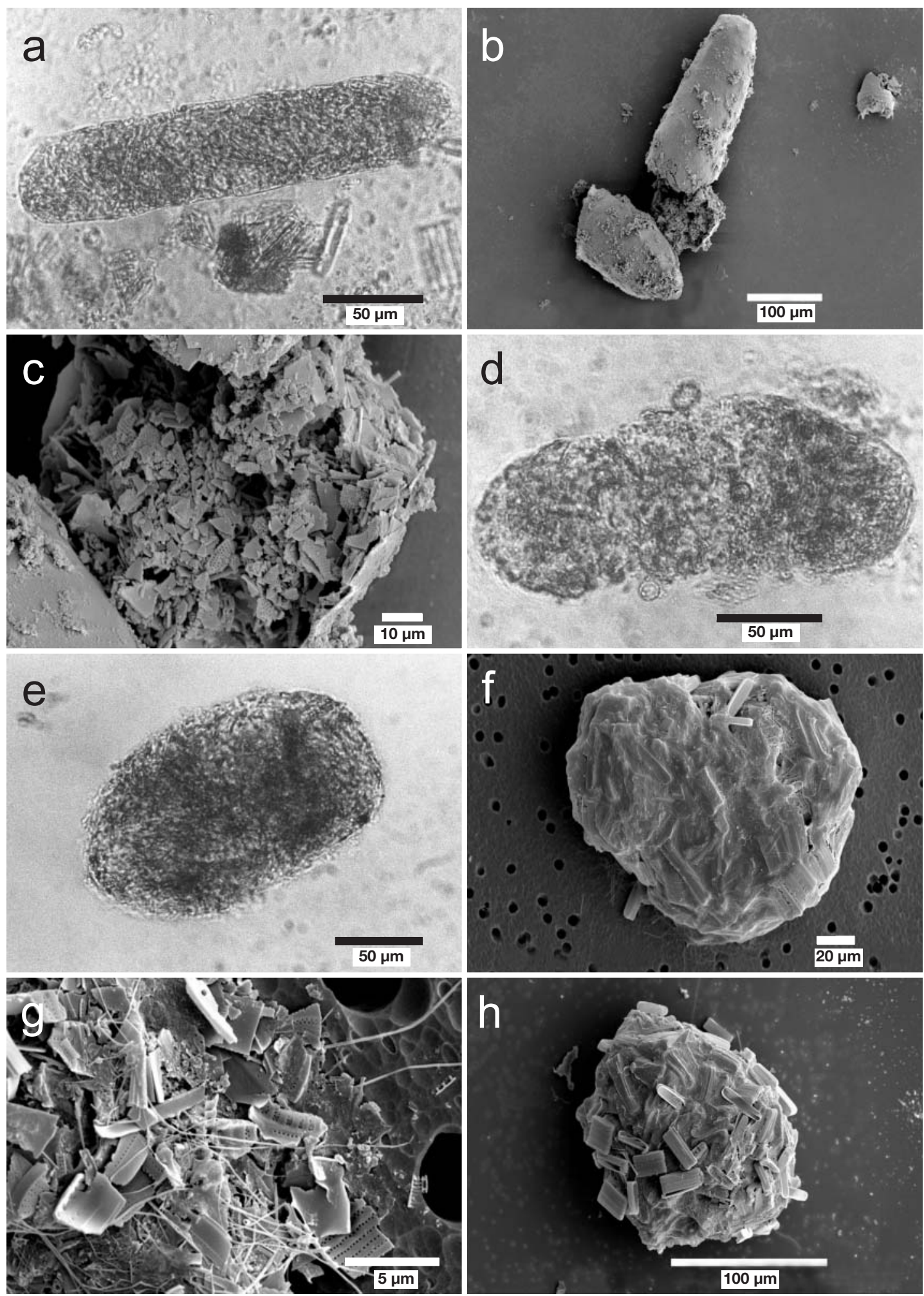

Fig. 3. Morphology and ultrastructure of cylindrical (a to d) and oval (e to h) pellets showing (a) LM of an intact cylindrical pellet with densely compacted contents, (b) SEM of a pellet broken in two, (c) SEM of pellet contents showing diatom fragments and a lack of interconnecting organic matter, (d) LM showing degradation of the bounding membrane of the pellet, (e) LM of a densely compacted oval pellet, (f) SEM of a pellet showing the shape of whole diatom frustules beneath the bounding membrane, ( $g$ ) SEM of pellet contents comprising diatom fragments, whole frustules and other organic matter, and (h) SEM showing whole diatom frustules adhered to the outer surface of the pellet 

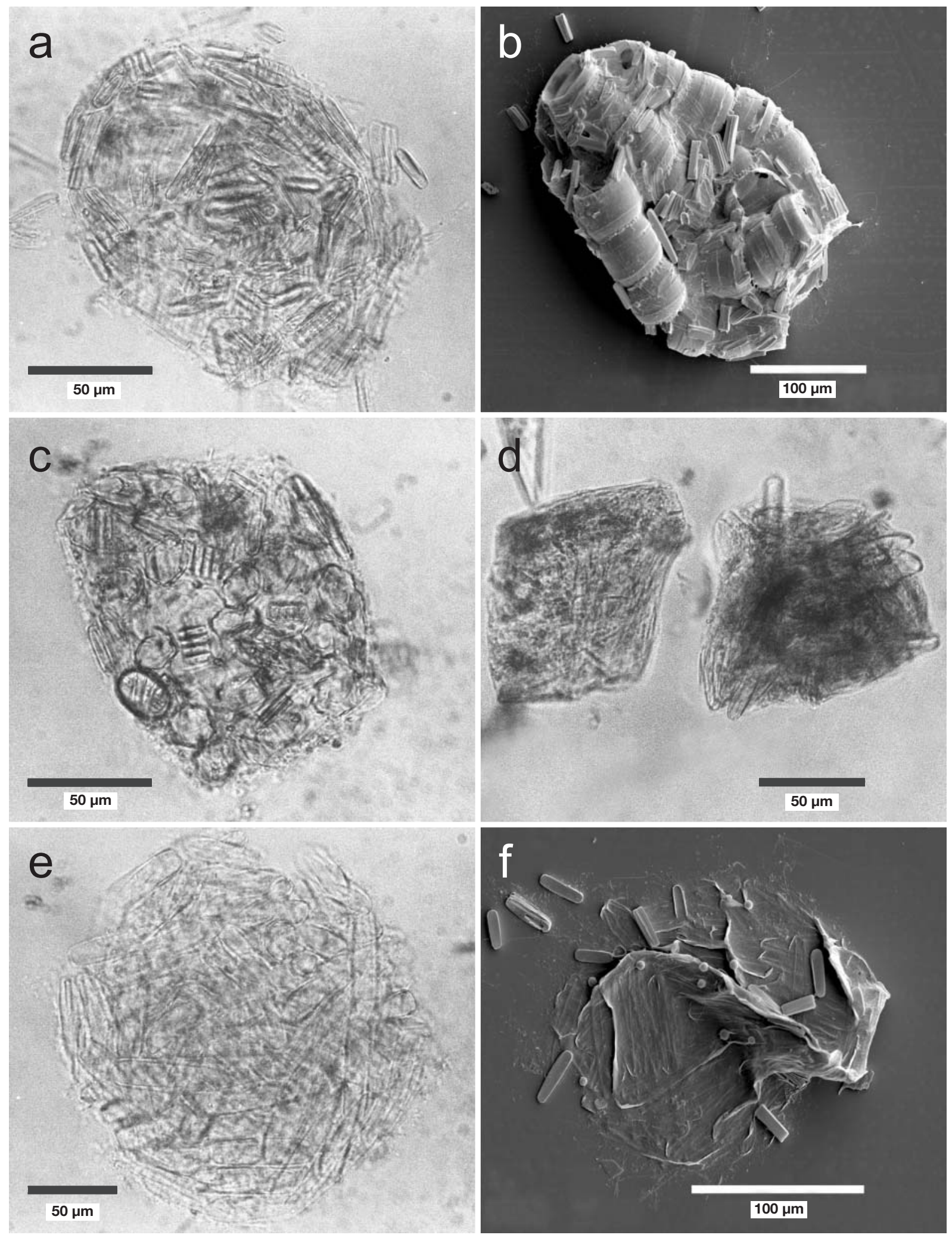

Fig. 4. Morphology and ultrastructure of pellets containing intact frustules showing (a) LM of an oval pellet containing monospecific pennate diatoms, (b) SEM of an oval pellet containing a chain of centric diatoms, probably a Thalassiosira sp., (c) LM of an oval pellet containing mixed diatom species, (d) LM of irregular pellets containing pennate diatoms, (e) LM of a large round pellet containing monospecific pennate diatoms, and (f) SEM of a ruptured pellet that has lost its structural integrity 

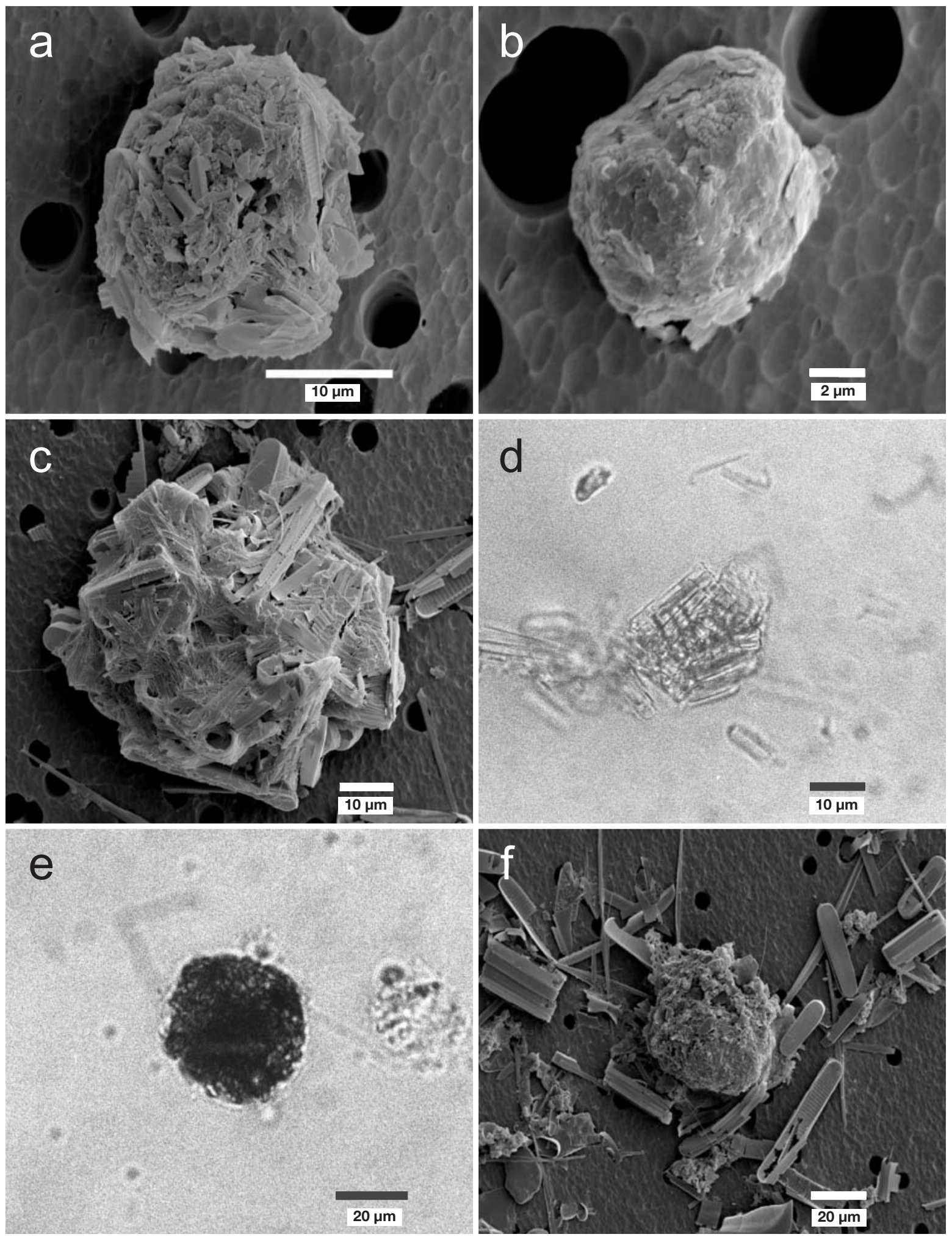

Fig. 5. Morphology and ultrastructure of minipellets showing (a) SEM of an oval consolidated minipellet comprising detritus and diatom fragments with no bounding membrane, (b) SEM of an oval consolidated minipellet with a bounding membrane, (c) SEM of a spherical consolidated minipellet comprising diatom fragments and whole frustules, (d) LM of a semi-transparent minipellet containing intact diatom frustules, (e) LM of a consolidated minipellet whose contents could not be discerned, and (f) SEM of a false minipellet that resembled the degraded end of a cylindrical pellet 
Metz 1998, MZC2 2001). These microzooplankton graze much of the primary production in upper waters and contribute to particle aggregation via the production of faecal pellets (Buck et al. 1990, Garrison 1991, Verity \& Vernet 1992, Metz 1998). It has been reported that particles $>100 \mu \mathrm{m}$ contribute most of the vertical carbon flux in the oceans (e.g. Fowler \& Knauer 1986, Williams et al. 1989, Fortier et al. 1994). However, surprisingly little work has been done to investigate species-specific differences among microzooplankton pellets, nor their persistence in the water column and contribution to this flux. Here we examine the distribution, abundance and ultrastructure of each faecal pellet type observed in sediment traps from Ellis Fjord and determine their likely producers and fate.

While significant correlations were observed between the abundance of plankton taxa and the flux of individual pellet types, we also observed nearsignificant $(0.05<\mathrm{p}<0.10)$ relationships where the magnitude of the slope was high and consistently positive or negative with depth. This indicated a consistent relationship between individual plankton taxa and pellet flux. These near-significant correlations suggest that the linkage between plankton and the vertical flux of their faecal pellets was affected by the mediation of pellet flux by trophic processes (e.g. coprophagy and microbial degradation) and the spatial and temporal variability in plankton and pellet abundance. The vertical distribution of copepods is reportedly highly variable and no consistent pattern of diel vertical migration has been observed in Ellis Fjord (Kirkwood 1993). Swimmers can also confound relationships between plankton and pellet flux by voiding their guts upon entering poisoned traps (Harbison \& Gilmer 1986). However, few swimmers were observed in trap material and in vitro studies of copepods (the most abundant swimmer) showed that animals did not void their guts upon contact with mercuric chloride and brine solution, nor did brine cause any herniation of copepod guts (Beaumont et al. in prep).

\section{Cylindrical pellets}

The abundance of Oncaea curvata and Paralabidocera antarctica in early summer coincided with the flux of cylindrical pellets in the water column. P. antarctica reportedly produces cylindrical pellets around 350 to $450 \mu \mathrm{m}$ long (Tanimura et al. 1984). The morphology of O. curvata pellets is unknown, but cylindrical pellets, ranging from 70 to $260 \mu \mathrm{m}$ in length, were produced by a temperate Oncaea sp. in the laboratory (Turner unpubl. data). There were no significant correlations between the abundance of these copepods and cylindrical pellets, although $P$. antarctica showed a near- significant relationship with these pellets at $\leq 10 \mathrm{~m}$ $(0.05<\mathrm{p}<0.10)$. The greatest flux of cylindrical pellets was observed at $40 \mathrm{~m}$, and resembled the abundance of $O$. curvata and P. antarctica between 10 and $20 \mathrm{~m}$, indicating these pellets persisted throughout the water column and contributed to vertical flux.

A negative relationship $(0.05<\mathrm{p}<0.10)$ between the abundance of Oithona similis and the flux of cylindrical pellets at all depths $\geq 5 \mathrm{~m}$ was observed, supporting the findings of González \& Smetacek (1994) that this copepod engages in coprophagy. Coprophagy in the water column can reportedly decrease the abundance of some pellets by up to $75 \%$ (González \& Smetacek 1994) and while Oncaea curvata dominated the copepod abundance, cylindrical pellets were the least abundant pellet-type collected in sediment traps. Cylindrical copepod pellets can contain undigested chl a (Bathmann \& Liebezeit 1986, Nelson 1989), and it has been suggested they may provide a nutrient source for other plankton (Smetacek 1980, González et al. 1994a). However, similar to Bathmann et al. (1987), we found that cylindrical pellets were easily damaged in the laboratory and degraded during preparation for SEM. Therefore, microbial and physical degradation could also have contributed to the overall low abundance of cylindrical pellets collected in sediment traps, particularly when heterotrophy predominated in the latter half of the season (Beaumont unpubl. data). The significant positive correlation between the abundance of $O$. similis and the flux of cylindrical pellets at $\leq 5 \mathrm{~m}$ suggests that coprophagy is facultative: high concentrations of protists, such as the ice-algal mat, may provide ample food and reduce coprophagous feeding.

Cylindrical pellets could be easily identified by their overall morphology using LM. The size $(>200 \mu \mathrm{m})$, shape (cylindrical) and optical density (opaque) were characteristic of 'typical' copepod pellets (Marshall \& Orr 1955, Honjo \& Roman 1978, Martens 1978). Furthermore, investigation of pellet ultrastructure using SEM showed that pellets predominantly contained compacted fragments of diatoms and occasional whole frustules reflecting raptorial feeding (González et al. 1994a), and showed little distortion of the bounding membrane.

\section{Oval pellets}

Oithona similis was abundant throughout the season and reportedly produces small oval pellets that can vary in size, even in the presence of a constant food source, ranging from 20 to $120 \mu \mathrm{m}$ (Martens 1978, González 1994a). The abundance of $O$. similis did not significantly correlate with that of oval pellets. However, correlations $(0.05<\mathrm{p}<0.10)$ were observed at 
$\leq 20 \mathrm{~m}$ in the water column where $O$. similis was most abundant suggesting that these copepods produced oval pellets (Table 3 ). To our knowledge, the shape of harpacticoid pellets has not been described. However, similar to $O$. similis, harpacticoids may produce oval pellets, as a weak correlation $(0.05<\mathrm{p}<0.10)$ was observed between the abundance of harpacticoids and oval pellet flux.

Oithona similis, harpacticoids and oval pellets were abundant in near-surface waters. While the maximum abundance of $O$. similis and harpacticoids occurred during mid to late summer, their concentrations were around 10 times less than that of Oncaea curvata. However, oval pellets were up to 50 times more abundant than cylindrical pellets. Similar to González (1992a), our laboratory observations suggest oval pellets were resistant to mechanical stress and microbial breakdown, and the high abundance of these pellets in surface waters relative to the concentration of their planktonic producers suggests that they may be persistent. Cadée et al. (1992) reported that oval pellets (150 to $350 \mu \mathrm{m}$ long) had relatively high sinking rates (80 to $250 \mathrm{~m} \mathrm{~d}^{-1}$ ). In contrast, our results, showing high pellet abundance in surface waters and low flux to depth indicated low sinking rates and eventual pellet breakdown. Many reasons have been proposed why pellet flux is retarded in the water column (Bathmann et al. 1987, Noji et al. 1991, González et al. 1994b) and we previously suggested that the low flux of oval pellets resulted from coprophagy (Beaumont et al. 2001). However, statistical analyses did not support this as there were no substantial negative relationships between the abundance of copepods and oval pellets.

Oval pellets produced by Oithona similis and harpacticoids, while relatively small, contained highly compacted diatom fragments as well as intact algal frustules typical of pellets produced by cyclopoid copepods (Adrian 1987). However, similar to pellet contents described from a temperate harpacticoid species (Dahms 1993), these pellets also contained nondiatomaceous and other organic material that may contribute to their reduced sinking rates (Bienfang 1980, Hansen et al. 1996, Feinberg \& Dam 1998).

\section{Pellets with intact frustules}

Pellets containing intact frustules were the second most abundant type of faecal pellet. These pellets resembled descriptions of pellets produced by protozoa (Stoecker 1984, Buck et al. 1990, Buck \& Newton 1995) however, the concentration of protozoa did not significantly correlate with the abundance of these pellets. The lack of correlation may be due to a number of factors. Firstly, this may have been an artefact of our sam- pling methods. We did not sample protozoa in the ice and they may have contributed substantially to the abundance of pellets in the water column. Furthermore, obtaining weekly 21 samples may not have encompassed the high spatial and temporal variability of the protozoan community. Fixation with Lugol's iodine may also have led to the loss of some organisms sampled. In addition, the accurate determination of the trophic status of dinoflagellate species is problematic, and estimates of protozoan abundance exhibited high variance due to their rare occurrence in microscope counts. Second, production of pellets may be variable due to the large amount of nutrition likely to be obtained from a single feeding event. Third, the variable abundance of these pellets may be due to high rates of degradation and disintegration of some pellets (see below).

Protozoan pellets were most abundant in the upper $10 \mathrm{~m}$ of the water column. They were relatively large (averaging $150 \mu \mathrm{m}$ in diameter) but contained intact diatom frustules, greatly reducing the density of siliceous material in the pellet (see below).

A large pellet volume relative to specific weight reportedly retards pellet flux (Madin 1982), and the low abundance of these pellets we observed at depth indicates that these large protozoan pellets contributed little to vertical flux. This agrees with the finding of González (1992b), but contrasts with that of Gowing et al. (2001) who reported large protozoan pellets sedimenting to depth. The morphology of ovoid pellets reported by Gowing et al. (2001) suggests they may not be of protozoan origin. However, differences in feeding mechanisms among protozoan genera could affect pellet morphology and production, and consequently the abundance and persistence of pellets in the water column.

Our observations of the morphology and ultrastructure of pellets containing intact frustules using LM and SEM showed 3 distinct morphological types. Oval pellets appeared the most compact and robust of the pellet types, and were frequently the most abundant protozoan pellet observed in sediment traps. These pellets were membrane-bound containing mixed diatoms or single diatom species and such pellets have previously been attributed to protozoans (Nöthig \& von Bodungen 1989, González 1992b). These oval pellets most resembled those produced by an athecate dinoflagellate in Antarctic sea-ice and underlying waters (Buck et al. 1990). Pasternak et al. (2000) recently reported that small larvaceans also produce oval pellets and these pellets contained only whole diatom frustules (A. Pasternak pers. comm.). However, larvaceans were not abundant in our study.

Irregular pellets were similar to those previously recorded in coastal waters (Nöthig \& von Bodungen 
1989, González 1992b, Buck \& Newton 1995, Saito et al. 1998), and are reportedly produced by heterotrophic dinoflagellates that directly engulf their prey (Elbrachter 1991, González 1992b, Buck \& Newton 1995). Gyrodinium spp. have been observed ingesting diatom chains and reportedly produce pellets containing monospecific diatom frustules similar to the irregular pellets we observed (Nöthig \& von Bodungen 1989, González 1992, Buck \& Newton 1995). Therefore, the Gyrodinium spp. that were abundant in our study are likely to have produced most of these irregular pellets (Table 3). However, other dinoflagellates that engulf their prey, such as heterotrophic Gymnodinium spp., could also have contributed to their production.

To our knowledge, the large, round, semi-transparent pellets we observed have only been reported in a single study in coastal waters off California, USA (Urrere \& Knauer 1981). Their large size and contents suggest they may be the pallium of extracellular feeding dinoflagellates that engulf and digest their prey within a feeding veil (termed a pallium), enabling them to feed upon prey items larger than their own body size (Gaines \& Taylor 1984, Jacobson \& Anderson 1986, Schnepf \& Elbrachter 1992). The pallium reportedly retracts after feeding and presumably the remains are dispersed (Elbrachter 1991). Therefore, we suggest these pellets may result from dislodgement of the pallium due to interruption while feeding, or if the pallium is renewed by the organism, and the occurrence of these pellets is likely to be rare. Members of the genus Protoperidinium spp. are known to be pallium-feeders (Gaines \& Taylor 1984, Hansen \& Calado 1999), and the Protoperidinium spp. we observed may have produced these pellets. Furthermore, we observed an unidentified HDIN with an apparent pallium that contained empty, compacted diatom frustules.

\section{Minipellets}

Minipellets were most abundant in the latter half of the season when HDIN and ciliates reached maximum concentration. These pellets are reportedly produced by a range of protozoa such as HDIN, ciliates, radiolarians and heterotrophic flagellates (Stoecker 1984, Gowing \& Silver 1985, Elbrachter 1991, Silver \& Gowing 1991). Radiolarians were not recorded in this study, and the methods we used would not have detected faeces produced by heterotrophic flagellates (see above). The abundance of HDIN, at depth intervals between 0 and $20 \mathrm{~m}$, significantly correlated with the flux of minipellets to 10 and $20 \mathrm{~m}$, while the abundance of ciliates at $\leq 10 \mathrm{~m}$ significantly correlated with minipellet flux to $10 \mathrm{~m}$. However, neither the abundance of HDIN nor ciliates significantly correlated with the highest abundance of minipellets recorded at $40 \mathrm{~m}$.

Minipellets, due to their size and morphology, are presumed to have low sinking rates and would not be expected to sink to depth (Stoecker 1984, Gowing \& Silver 1985, Elbrachter 1991). However, similar to our findings, they have often been recorded in high abundance in deep waters (Gowing \& Silver 1985, Nöthig \& von Bodungen 1989, González et al. 1994b). The morphology of minipellets was difficult to discern using LM as they were small and generally opaque. Observations of their morphology using SEM showed there were 4 types of minipellets.

Oval minipellets, containing detritus and small diatom fragments, were observed both with and without a bounding membrane and resembled pellets produced by both dinoflagellates and ciliates (Stoecker 1984, Buck et al. 1990, Elbrachter 1991).

Small, spherical minipellets were similar in structure and contents to the dense oval pellets produced by Oithona similis and harpacticoids (see 'Oval pellets'), and the size of these minipellets was similar to those produced by copepod nauplii in the laboratory (Pasternak et al. 2000). Copepod nauplii were only occasionally observed in net haul samples but the mesh size of our net $(100 \mu \mathrm{m})$ probably under-sampled these organisms (see Pasternak et al. 2000). Thus, these spherical minipellets were probably produced by copepod nauplii.

Semi-transparent minipellets containing whole diatom frustules resembled the irregular pellets that we attributed to phagotrophic dinoflagellates (see above). These pellets have previously been recorded from Antarctic waters across a broad size range (5 to $120 \mu \mathrm{m}$ ) (González 1992b), their size reportedly being determined by the quantity and species composition of available food (Elbrachter 1991). Therefore, dinoflagellates appear capable of producing faecal pellets of variable size, from minipellets to pellets comparable in size, or larger than, those produced by small copepods.

The fourth type of minipellet we observed resembled the degraded end of a cylindrical pellet and we termed these 'false minipellets'. Faecal pellets reportedly degrade as they sink (Honjo \& Roman 1978, Martens \& Krause 1990), and coprophagy and ablation in the water column fragments pellets and aids their degradation by microbes (Honjo \& Roman 1978, Lampitt et al. 1990, Noji et al. 1991). Statistical analyses showed significant correlations between the abundances of Oithona similis and harpacticoids and minipellet flux to 20 and $40 \mathrm{~m}$ respectively. Therefore, coprophagy of cylindrical pellets by $O$. similis and harpacticoids may have contributed to the production of false minipellets. Furthermore, the lack of correlation between protozoan abundance and minipellet flux to depth suggests that false minipellets comprised the majority of mini- 
pellets in sediment traps at $40 \mathrm{~m}$. Therefore, production of false minipellets due to coprophagy and degradation may assist in explaining the abundance of minipellets in deep waters reported in previous studies (see above).

Most studies investigating particle flux have used only LM to examine faecal pellet morphology and abundance. While LM is necessary for quantitative analysis of sediment trap material, it limits the ability to resolve detailed structure and morphology of pellets. Under the light microscope, we observed copepod pellets that appeared free of external matter. However, when viewed using SEM, whole diatoms were observed adhered to the outer surface of the pellet that may be confused with pellet contents under the light microscope. Furthermore, previous studies have reported difficulties in distinguishing faecal pellets from protozoa when viewed by LM (Nöthig \& von Bodungen 1989, Gowing et al. 2001). Therefore, we propose that the classification of faecal pellets using LM be validated using SEM.

\section{Contribution by copepods and protozoa to vertical flux}

It is generally believed that heterotrophic grazing facilitates the export of primary production, and biogenic particles greater than $100 \mu \mathrm{m}$ are primarily responsible for vertical carbon flux in the oceans (e.g. Fowler \& Knauer 1986, Williams et al. 1989, Fortier et al. 1994). However, in northern hemisphere waters, the retention of a variety of pellet types (large cylindrical, oval, protozoan, minipellets) has been observed (Smetacek 1980, Hofmann et al. 1981, Martens \& Krause 1990, Wassmann et al. 1994, Vittasalo et al. 1999, Pasternak et al. 2000). In Antarctic waters there has been little consensus on the fate of faecal pellets. Large cylindrical pellets have been reported to be retained in upper waters, but in conjunction with oval pellets they can also contribute to vertical flux (Bathmann et al. 1991, Cadée et al. 1992, González 1992a, Suzuki et al. 2001). Furthermore, it has been proposed that protozoan pellets can contribute significantly to carbon export (Nöthig \& von Bodungen 1989, Buck et al. 1990, Bathmann et al. 1991, González 1992a, Gowing et al. 2001). We found that small cylindrical pellets from Oncaea curvata and Paralabidocera antarctica can also sediment to depth. However, oval pellets produced by Oithona similis and small harpacticoid copepods, and protozoan pellets were retained in upper waters irrespective of their diverse range in size, shape and ultrastructure. Our results indicate that the contribution by microzooplankton to vertical carbon flux is largely determined by the species-specific origin of the pellets that defines their structure and morphology, rather than pellet size. Consequently, changes in community structure over fine spatial and temporal scales and due to long-term global climate change will influence the role of the plankton community in vertical carbon flux, with ramifications for the accumulation of greenhouse gases in the atmosphere.

Acknowledgements. We acknowledge the assistance of Anthony Plummer and the 1997/98 Davis station personnel, and we thank David Ritz, Graham Hosie, Kerrie Swadling, Stephen Nicol and 4 anonymous referees for their comments and discussion that greatly improved this manuscript. This research was supported by the Antarctic Science Advisory Committee Grants 963 and 2227, and an Australian Postgraduate Award.

\section{LITERATURE CITED}

Adrian R (1987) Viability of phytoplankton in fecal pellets of two cyclopoid copepods. Arch Hydrobiol 110:321-330

Atkinson A, Sinclair JD (2000) Zonal distribution and seasonal vertical migration of copepod assemblages in the Scotia Sea. Polar Biol 23:46-58

Azam F (1998) Microbial control of oceanic carbon flux: the plot thickens. Science 280:694-696

Banse K (1995) Zooplankton: pivotal role in the control of ocean production. ICES J Mar Sci 52:265-277

Bathmann UV (1996) Abiotic and biotic forcing on vertical particle flux in the Southern Ocean. In: Ittekot PSV, Honjo S, Depetris PJ (eds) Particle flux in the ocean. John Wiley \& Sons, Chichester, p 243-250

Bathmann UV, Liebezeit G (1986) Chlorophyll in copepod faecal pellets: changes in pellet numbers and pigment content during a declining Baltic spring bloom. PSZN I: Mar Ecol 7:59-73

Bathmann UV, Noji TT, Voss M, Peinert R (1987) Copepod fecal pellets: abundance, sedimentation and content at a permanent station in the Norwegian Sea in May/June 1986. Mar Ecol Prog Ser 38:45-51

Bathmann UV, Fischer G, Müller PJ, Gerdes D (1991) Shortterm variations in particulate matter sedimentation off Kapp Norvegia, Weddell Sea, Antarctica: relation to water mass advection, ice cover, plankton biomass and feeding activity. Polar Biol 11:185-195

Battarbee RW (1986) Diatom analysis. In: Berglund BE (ed) Handbook of holocene palaeoecology and palaeohydrology. John Wiley \& Sons, Chichester, p 527-570

Beaumont KL, Plummer AJ, Hosie GW, Ritz DA (2001) Production and fate of faecal pellets during summer in an East Antarctic fjord. Hydrobiologia 453/454:55-65

Bienfang PK (1980) Herbivore diet affects fecal pellet settling. Can J Fish Aquat Sci 37:1352-1357

Bloesch J, Burns NM (1980) A critical review of sedimentation trap technique. Schweiz Z Hydrol 42:15-55

Buck KR, Newton J (1995) Fecal pellet flux in Dabob Bay during a diatom bloom: contribution of microzooplankton. Limnol Oceanogr 40:306-315

Buck KR, Bolt PA, Garrison DL (1990) Phagotrophy and fecal pellet production by an athecate dinoflagellate in Antarctic sea ice. Mar Ecol Prog Ser 60:75-84

Cadée GC, González H, Schnack-Schiel SB (1992) Krill diet affects faecal string settling. Polar Biol 12:75-80

Christian JR, Karl DM (1995) Measuring bacterial ectoen- 
zyme activities in marine waters using mercuric chloride as a preservative and a control. Mar Ecol Prog Ser 123: 217-224

Dahms H (1993) Internal anatomy of female Paramphiascella fulvofasciata (Copepoda, Harpacticoida). Can J Zool 71: $1242-1250$

Elbrachter M (1991) Faeces production by dinoflagellates and other small flagellates. Mar Microb Food Webs 5:189-204

Falkowski PG, Barber RT, Smetacek V (1998) Biogeochemical controls and feedbacks on ocean primary production. Science 281:200-206

Feinberg LR, Dam HG (1998) Effects of diet on dimensions, density and sinking rates of fecal pellets of the copepod Acartia tonsa. Mar Ecol Prog Ser 175:87-96

Fenchel T (1988) Marine plankton food chains. Annu Rev Ecol Syst 19:19-38

Fortier L, Le Fevre J, Legendre L (1994) Export of biogenic carbn to fish and to the deep ocean: the role of large planktonic microphages. J Plankton Res 16:809-839

Fowler SW, Knauer GA (1986) Role of large particles in the transport of elements and organic compounds through the oceanic water column. Prog Oceanogr 16:147-194

Fransz HG, González SR (1995) The production of Oithona similis (Copepoda: Cylopoida) in the Southern Ocean. ICES J Mar Sci 52:549-555

Froneman PW, Perissinotto R (1996) Microzooplankton grazing and protozooplankton community structure in the South Atlantic and in the Atlantic sector of the Southern Ocean. Deep-Sea Res Part A 43:703-721

Gaines G, Taylor FJR (1984) Extracellular digestion in marine dinoflagellates. J Plankton Res 6:1057-1061

Garrison DL (1991) An overview of the abundance and role of protozooplankton in Antarctic waters. J Mar Syst 2: 317-331

Gibson JAE (1998) Carbon flow through inshore marine environments of the Vestfold Hills, East Antarctica. ANARE Scientific Rep 139:1-221

Gibson JAE (1999) The role of ice in determining mixing intensity in Ellis Fjord, Vestfold Hills, East Antarctica. Antarct Sci 11:419-426

González HE (1992a) The distribution and abundance of krill faecal material and oval pellets in the Scotia and Weddell Seas (Antarctica) and their role in particle flux. Polar Biol 12:81-91

González HE (1992b) Distribution and abundance of minipellets around the Antarctic peninsula. Implications for protistan feeding behaviour. Mar Ecol Prog Ser 90:223-236

González HE, Smetacek V (1994) The possible role of the cyclopoid copepod Oithona in retarding vertical flux of zooplankton faecal material. Mar Ecol Prog Ser 113: 233-246

González HE, Kurbjeweit F, Bathmann UV (1994a) Occurrence of cyclopoid copepods and faecal material in the Halley Bay region, Antarctica, during January-February 1991. Polar Biol 14:331-342

González HE, González SR, Brummer GJA (1994b) Shortterm sedimentation pattern of zooplankton, faeces and microplankton at a permanent station in the Bjornafjorden (Norway) during April-May 1992. Mar Ecol Prog Ser 105: $31-45$

González HE, Ortiz VC, Sobarzo M (2000) The role of faecal material in the particulate organic carbon flux in the northern Humboldt Current, Chile $\left(23^{\circ} \mathrm{S}\right)$, before and during the 1997-1998 El Niño. J Plankton Res 22:499-529

Gowing MM, Silver MW (1985) Minipellets: a new and abundant size class of marine fecal pellets. J Mar Res 43: $395-418$
Gowing MM, Garrison DL, Kunze HB, Winchell CJ (2001) Bio logical components of Ross Sea short-term particle fluxes in the austral summer of 1995-1996. Deep-Sea Res Part A 48:2645-2671

Hansen B, Fotel FL, Jensen NJ, Madsen SD (1996) Bacteria associated with a marine planktonic copepod in culture. II. Degradation of fecal pellets produced on a diatom, a nanoflagellate or a dinoflagellate diet. J Plankton Res 18: 275-288

Hansen PJ, Calado AJ (1999) Phagotrophic mechanisms and prey selection in free-living dinoflagellates. J Eukaryot Microbiol 46:382-389

Harbison GR, Gilmer RW (1986) Effects of animal behaviour on sediment trap collections: implications for the calculation of aragonite fluxes. Deep-Sea Res Part A 33: $1017-1024$

Hofmann EE, Klinck JM, Paffenhofer G-A (1981) Concentrations and vertical fluxes of zooplankton fecal pellets on a continental shelf. Mar Biol 61:327-335

Honjo S, Roman MR (1978) Marine copepod fecal pellets: production, preservation and sedimentation. J Mar Res 36: $45-57$

Jacobson DM, Anderson DM (1986) Thecate heterotrophic dinoflagellates: feeding behaviour and mechanisms. J Phycol 22:249-258

Kirkwood JM (1993) Zooplankton community dynamics and diel vertical migration in Ellis Fjord, Vestfold Hills, Antarctica. PhD thesis, Monash University, Melbourne

Kirkwood JM, Burton HR (1987) Three new zooplankton nets designed for under-ice sampling; with preliminary results of collections made from Ellis fjord, Antarctica during 1985. Proc NIPR Symp. Polar Biol 1:112-122

Knauer GA, Karl DM, Martin JH, Hunter CN (1984) In situ effects of selected preservatives on total carbon, nitrogen and metals collected in sediment traps. J Mar Res 42: 445-462

Lampitt RS, Noji T, von Bodungen B (1990) What happens to zooplankton faecal pellets? Implications for material flux. Mar Biol 104:15-23

Lee C, Hedges JI, Wakeham SG, Zhu N (1992) Effectiveness of various treatments in retarding microbial activity in sediment trap material and their effects on the collection of swimmers. Limnol Oceanogr 37:117-130

Le Fevre J, Legendre L, Rivkin RB (1998) Fluxes of biogenic carbon in the Southern Ocean: roles of large microphagous zooplankton. J Mar Syst 17:325-345

Lessard EJ (1991) The trophic role of heterotrophic dinoflagellates in diverse marine environments. Mar Microb Food Webs 5:49-58

Madin LP (1982) Production, composition and sedimentation of salp fecal pellets in oceanic waters. Mar Biol 67:39-45

Marchant HJ, Thomas DP (1983) Polylysine as an adhesive for the attachment of nanoplankton to substrates for electron microscopy. J Microsc 131:127-129

Marshall SM, Orr AP (1955) The Biology of a marine copepod Calanus finmarchicus (Gunnerus). Oliver \& Boyd, London

Martens P (1978) Faecal pellets. Fiches d'identification du zooplancton 162, ICES, Copenhagen

Martens P, Krause M (1990) The fate of faecal pellets in the North Sea. Helgol Meeresunters 44:9-19

McMinn A (1994) Preliminary investigation of a method for determining past winter tempereatures at Ellis Fjord, eastern Antarctica, from fast ice assemblages. Mem Natl Inst Polar Res Spec Issue 50:34-40

Metz C (1998) Feeding of Oncaea curvata (Poecilostomatoida, Copepoda). Mar Ecol Prog Ser 169:229-235

MZC2 (Marine Zooplankton Colloqium 2) (2001) Future 
marine zooplankton research-a perspective. Mar Ecol Prog Ser 222:297-308

Nelson JR (1989) Phytoplankton pigments in macrozooplankton feces: variability in carotenoid alterations. Mar Ecol Prog Ser 52:129-144

Noji T (1991) The influence of macrozooplankton on vertical particulate flux. Sarsia 76:1-9

Noji TT, Estep KW, MacIntyre F, Norrbin F (1991) Image analysis of faecal material grazed upon by three species of copepods: evidence for coprorhexy, coprophagy and coprochaly. J Mar Biol Assoc UK 71:465-480

Nöthig EM, Bodungen BV (1989) Occurrence and vertical flux of faecal pellets of probably protozoan origin in the southeastern Weddell Sea (Antarctica). Mar Ecol Prog Ser 56:281-289

Pasternak A, Arashkevich E, Wexels Riser CW, Ratkova T, Wassmann P (2000) Seasonal variation in zooplankton and suspended faecal pellets in the subarctic Norwegian Balsfjorden, in 1996. Sarsia 85:439-452

Reeve MR, Walter MA (1978) Nutritional ecology of ctenophores - a review of recent research. Adv Mar Biol 15: 249-287

Rivkin RB, Legendre L (2001) Biogenic carbon cycling in the upper ocean: effects of microbial respiration. Science 291:2398-2400

Rosa F, Bloesch J, Rathke DE (1994) Sampling the settling and suspended particulate matter (SPM). In: Murdoch A, MacKnight SD (eds) Handbook of techniques for aquatic sediments sampling. Lewis Publishers, Boca Raton, p 97-129

Saito R, Kudoh S, Sato T, Watanabe K, Fukuchi M (1998) Composition of sinking particulates collected under fast ice near Syowa station, East Antarctica, in early spring and early summer, 1994. Antarct Rec 42:252-268

Schnepf E, Elbrachter M (1992) Nutritional strategies in dinoflagellates: a review with emphasis on cell biological aspects. Eur J Protistol 28:3-24

Silver MW, Gowing MM (1991) The 'particle' flux: origins and biological components. Prog Oceanogr 26:75-113

Smetacek VS (1980) Zooplankton standing stock, copepod faecal pellets and particulate detritus in Kiel Bight. Estuar Coast Mar Sci 11:477-490

Steedman HFE (1976) Zooplankton fixation and preservation. UNESCO, Paris

Stoecker DK (1984) Particle production by planktonic ciliates. Limnol Oceanogr 29:930-940

Suzuki H, Sasaki H, Fukuchi M (2001) Short-term variability

Editorial responsibility: Otto Kinne (Editor),

Oldendorf/Luhe, Germany in the flux of rapidly sinking particles in the Antarctic marginal ice zone. Polar Biol 24:697-705

Swadling K, Gibson JAE, Ritz DA, Nichols PD, Hughes DE (1997) Grazing of phytoplankton by copepods in eastern Antarctic coastal waters. Mar Biol 128:39-48

Tanimura A, Minoda T, Fukuchi M, Hoshiai T, Ohtsuka H (1984) Swarm of Paralabidocera antarctica (Calanoida, Copepoda) under sea ice near Syowa Station, Antarctica. Antarct Rec 82:12-19

Tomas CRE (1996) Identifying marine diatoms and dinoflagellates. Academic Press, California

Trull TW, Gibson JAE, Beaumont KL, Bowman J and 10 others (2001) Site holds promise for ecosystem and biogeochemical investigations. EOS Trans Am Geophys Union $82: 306,311$

Turner JT (1984) Zooplankton feeding ecology: contents of fecal pellets of the copepods Temora turbinata and T. stylifera from continental shelf and slope waters near the mouth of the Mississippi River. Mar Biol 82:73-83

Turner JT (2000) Feeding ecology of marine copepods: an overview of recent studies and emerging issues. Natl Taiwan Museum Spec Publ Ser 10:37-57

Urrere MA, Knauer GA (1981) Zooplankton fecal pellet fluxes and vertical transport of particulate organic material in the pelagic environment. J Plankton Res 3:369-387

Verity P, Smetacek V (1996) Organism life cycles, predation, and the structure of marine pelagic ecosystems. Mar Ecol Prog Ser 130:277-293

Verity PG, Vernet M (1992) Microzooplankton grazing, pigments, and composition of plankton communities during late spring in two Norwegian fjords. Sarsia 77:263-274

Viitasalo M, Rosenberg M, Heiskanen AS, Kosi M (1999) Sedimentation of copepod fecal material in the coastal northern Baltic Sea: Where did all the pellets go? Limnol Oceanogr 44:1388-1399

Wassmann P (1998) Retention versus export food chains: processes controlling sinking loss from marine pelagic systems. Hydrobiologia 363:29-57

Wassmann P, Martinez R, Vernet M (1994) Respiration and biochemical composition of sedimenting organic matter during summer in the Barents Sea. Cont Shelf Res 14: 79-90

Williams PJleB, von Bodungen B, Bathmann U, Berger WH and 8 others (1989) Group report: export productivity from the photic zone. In: Berger WH, Smetacek VS, Wefer G (eds) Productivity of the ocean: present and past. John Wiley \& Sons, Chichester, p 99-115

Submitted: May 6, 2002; Accepted: July 26, 2002

Proofs received from author(s): December 6, 2002 